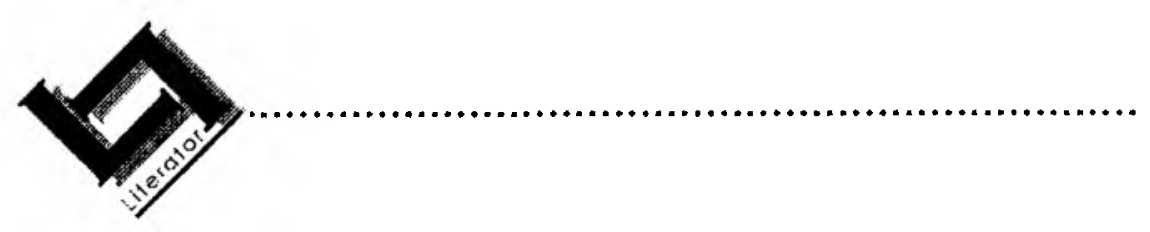

\title{
Die Anglo-Boereoorlog: 'n vertekende beeld vanuit die vreemde
}

\author{
Jacques van der Elst \\ Skool vir Tale en Kunste (Afrikaans \& Nederlands) \\ Potchefstroomse Universiteit vir $\mathrm{CHO}$ \\ POTCHEFSTROOM \\ E-pos: dlwjvde@puknet.puk.ac.za
}

\section{Abstract}

The Anglo-Boer War: A distorted image from abroad

This article deals with the Dutch author Louwrens Penning (1854-1927) who wrote 18 novels on the Boer War, even though he never visited the country until 1924, long after the Anglo-Boer War had ended One of his books, entuled De held van Spionkop, is discussed as example.

Penning s images of the Boer warriors and their endeavors were highly idealised and embedded in a certain view of race relations and war. He created idols, like the courageous boy named Blikoortie, which became widely known among his Dutch readers, especially the Dutch youth. He facilely ignored historic facts and rather idealized and fantasized. His works thus became a peculiar mixture of fact and fiction. Though he was not a literary master, he succeeded in writing gripping stories which were - up to a point - reprinted time and again.

Through his writings he succeeded in creating a positive image of the Afrikaner which persisted in spite of the negative outcome of apartheid. Though one cannot be sure, it may even be true that Dutch immigrants came to South Africa because of a consistently positive image of Afrikaans and Afrikaans heroes as created by Penning in his books. 


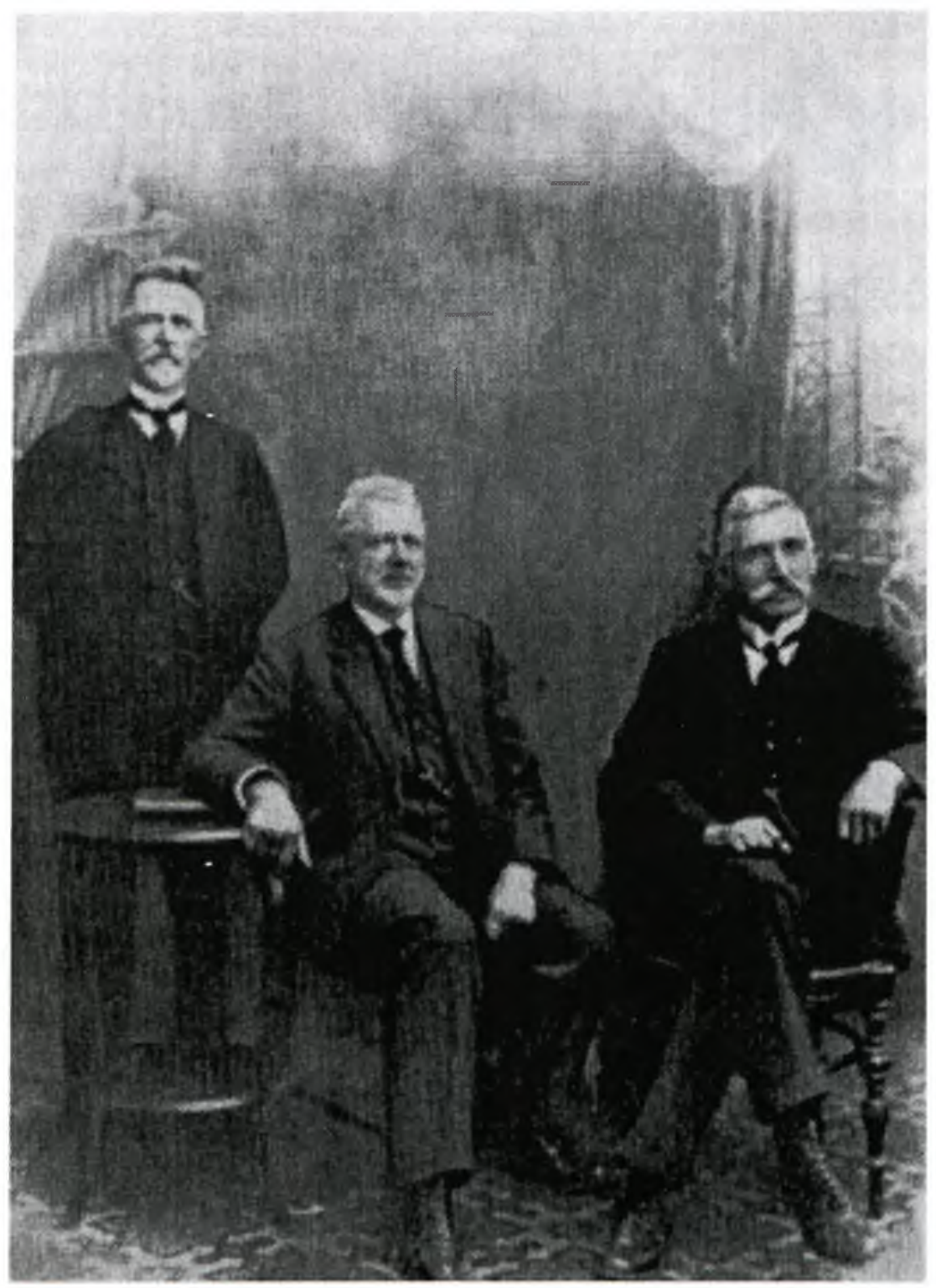

“Oubaas" Penning (middel) saam met sy broers, Gerrit en Arie, tydens sy eerste en enigste besoek aan Suid-Afrika in 1924. 


\section{Inleidend}

Louwrens Penning (1854-1927) se naam word in Nederland tot op hede (1999) verbind met die Anglo-Anglo-Boereoorlog. Wat die gemiddelde Nederlander van die oorlogsgebeure 1899-1901 weet, het hy meesal afgelei uit wat Penning daarvan verbeeld het

Die merkwaardigste is dat Penning die Boerehelde nie van naby geken het nie; dat hy nooit die geweer- en kanonvuur van die slagvelde van naby beleef het nie en dat hy Suid-Afrika eers in 1924 besoek het toe hy 70 was en kennis gemaak het met die Suid-Afrikaanse landskap met sy "koppies" en kenmerkende plantegroei waaroor hy so baie geskryf het. Nietemin het hy 18 werke oor die Anglo-Anglo-Boereoorlog en oor die Boere-geskiedenis in die algemeen geskryf. Een daarvan is De held van Spionkop waaraan in hierdie artikel besondere aandag bestee word.

Vir die Suid-Afrikaanse leser het hy 'n beeld van die Anglo-Boereoorlog geskep wat eintlik verwing is. Hy het wel sekere historiese datums en feite van gebeurtenisse gehandhaaf, maar hy het vir sy Nederlandse lesers 'n beeld van die oorlog en van die Afrikaner geskep wat eintlik verteken is. In hierdie artikel word die vertekenings of verwringings bespreek en word die moontlike agtergronde daarvan of motiverings daarvoor, veral met betrekking tot die prosesse van idealisering en ideologisering, gesinjaleer.

Reeds sy naamgewing van die Boerekrygers en die Engelse soldate en die ander "figurante" in De held van Spionkop is vreemdsoortig vir Suid-Afrikaanse omstandighede. Die Potgieters se swart bediende kry die naam Trijntje. Die name van Britse soldate wat die Potgieters se huis afgebrand het, is nog vreemder: die lange lui Ben en dikke Cas. Die Potgieters se hond het 'n egte Nederlandse hondenaam, Bello. Een van die Wessels-broers kry verder die onwaarskynlike eg Nederlandse naam Kees.

Soms grens sekere toneelbeskrywings aan naïwiteit en belaglikheid. Wanneer die Engelse magte byvoorbeeld onder die beskerming van die nag die Spioenkop bekruip, word hulle verskrik deur "een witte gedaante". Dis gelukkig vals alarm! "Het is een witte keeshond, waarschijnlijk aan de een of andere Boer toebehorende; hij komt rustig aantrippelen ..." (s.j.a:177). Dis onwaarskynlik dat die Boere juis wit keeshonde sou hê, en as hulle keeshonde sou gehad het, lyk dit nog meer onmoontlik dat een van hulle die Engelse se pad op so 'n spannende oomblik sou kruis.

Penning se hantering van die Afrikaanse dialoog laat veel te wense oor. Dit word beskryf as 'n onberkenbaar verminkte Nederlands wat in latere herdrukke deur een van sy kleinseuns taalkundig reggestel is (Jonker, 1969). 
Uiteindelik het Penning die Nederlandse leser "geakkommodeer" en geweldig sukses behaal. Sy werke het tot 1969 herdruk op herdruk beleef. 'n Opvolgartikel sou aan die edisie- en leesgeskiedenis van Penning se werke gewy kon word. So 'n ondersoek moet egter ter plaatse in Nederland onderneem word.

In sy outobiografie beskryf hy hoe hy met die lot van die Boererepublieke kennis gemaak het. Sy skryflus vir die Boeresaak het sterker geword op grond van die Jameson-inval. Sy ontsteltenis oor dié gebeure was so hewig dat hy op Nuwejaarsdag, 1895/1896, in die hartjie van die winter in Europa, twee keer 'n koue stortbad geneem en toe 'n gedig oor die "aartsbandiet" Jameson se nederlaag by Doornkop geskryf het. Dit was nie genoeg nie - teen die advies van ds. Frans Lion Cachet wat toe in Nederland was, het hy 'n vervolgverhaal oor die Groot Trek in De drie provinciën, 'n koerant waarvoor hy buitelandse korrespondent was, begin skryf. Ds. Frans Lion Cachet was die broer van ds. Jan Lion Cachet (later professor) van Sewe-duiwels-faam. Frans Lion Cachet, wie se spoor deur J.L. Ras (1981) gevolg word, was van 1858 af predikant in die N.G. Kerk. Hy was later vir tydperke predikant in Nederland waar Penning hom geraadpleeg het. Cachet was outeur van 'n monumentale werk van 660 bladsye, getitel De worstelstryd der Transvalers aan het volk van Nederland verhaald (1882), 'n werk wat Penning vir seker as bron vir sy skryfwerk geraadpleeg het. Ds. Lion Cachet het in sy negatiewe advies gesê dat Penning 'n karikatuur, 'n spotbeeld, van die Boere sou maak. Penning het deurgedruk en sy eerste geskrif as 'n koerantvervolgverhaal voltooi. Dit was ook die teks vir sy eerste boek (s.j.c.) De helden van Zuid-Afrika: een verhaal uit den "trek" der Afrikaansche Boeren uit de Kaapkolonie naar de Transvaal wat 'n gesamentlike uitgawe was van die uitgewer F. Duym in Gorkum en die skrywer self.

Die bronne vir sy boeke was vir die skrywer nie 'n probleem nie. Daar het boeke oor die Groot Trek verskyn, onder andere die bovermelde werk van Lion Cachet. Hy het egter baie gemaklik oor die hindernisse van feitelikheid en realiteit geseil. In sy outobiografie, wat postuum verskyn het, skryf hy die volgende: "Maar ik was in mijn ziel overtuigd, iets anders te zullen leveren dan caricaturen. Ik had mijn verbindingen in Zuid-Afrika en ik schreed moedig over alle hinderpalen heen" (s.j.b:138).

Met die "verbindingen" verwys hy stellig na sy twee broers, Gerrit en Arie, wat reeds voor 1884 na Suid-Afrika verhuis het. Dit was trouens so hittete of Penning sou self in 1884 ook verhuis het indien sy bejaarde moeder se pleidooi om te bly hom nie gekeer het nie (s.j.b: 134, 135). Toe hy later oor die gebeure van die Anglo-Anglo-Boereoorlog skryf, benut hy benewens die gebruiklike koerant- en nuusberigte ook die inligting uit briewe wat hy van sy broers ontvang. 
Dit is egter duidelik dat Penning, om enigsins substansie aan sy verhale te verleen, 'n oordosis van sy verbeelding moes gebruik om die boeke te skryf wat uiteindelik sy omvangryke oeuvre gevorm het.

Hierdie verbeelding is gelaai met ' $n$ ideologiese en idealistiese siening wat waarskynlik vir die Suid-Afrikaanse leser, veral die hedendaagse SuidAfrikaanse leser, tot op 'n sekere hoogte 'n karikatuuragtige beeld van SuidAfrika en veral dan van die Anglo-Boereoorlog geskep het. Wat vir die SuidAfrikaanse leser 'n realiteit was, het nie vir die Nederlandse leser gegeld nie. Die korrektief van die realiteit van die Afrikaner, die Suid-Afrikaanse landskap en die plaaslewe in die algemeen het by die gemiddelde Nederlandse leser ontbreek. Dit is ook veral die spannende gebeurtenisse, die heldedade in oorlogstyd in ' $n$ boeiende landskap wat die Nederlandse leser aangegryp het en die sukses van Penning se boeke verseker het.

In die volgende afdeling word, met toespitsing op Penning se werk De held van Spionkop (s.j.a) ingegaan op die ideologiese en idealistiese aspekte van die betrokke teks. Vermoedelik het die eerste uitgawe van die teks in 1901 verskyn.

Ideologieë hou veral verband met 'n bepaalde lewens- en wêreldbeskouing oor universele sake, in hierdie geval oor menseverhoudings en oorlogvoering. Penning word deur ' $n$ byna blinde idealisering en heldeverering van en vir die Boere geïnspireer. Dit hou ook verband met die tydsgees waarin Penning geleef het. Hy het in sy werk die simpatie vertolk wat in sekere Wes-Europese lande vir die verdrukte Boerenasie bestaan het, en wat gekulmineer het in Koningin Wilhelmina van Nederland se besluit om die Gelderland te stuur om die bejaarde Paul Kruger te gaan haal. Binne Europese verband het Penning in Nederland in ell deur sy werk 'n beeld of "imago" (Van Gorp et al., 1991:190) geskep wat gehelp het om die sukses van sy werk in sy eie land te verbeter. Hy het daarin geslaag om die Boere en hul stryd positief te stereotipeer en meegewerk aan, wat Van Gorp noem, "een globaal beeld van een bepaalde cultuur ..."; dus van SuidAfrika buite Suid-Afrika se landsgrense. Dat dié globale beeld nie feitelik korrek was nie, doen geen afbreuk aan die bestaan van so 'n beeld nie.

\section{Ideologiese waardes}

\subsection{Rasseverhoudings}

Dit is merkwaardig hoe Penning hom die negatiewe stereotiperings van swartes toegeëien het. Hy moes wel die essensie van die negatiewe rasseverhoudings uit sy kontak met sy broers, die berigte oor die oorlog en ander inligtingsbronne afgelei het. Ook moes daar in sy eie omgewing konsepte oor swart mense bestaan het wat hy in sy verhale verwerk het. Die identifikasie van swart met heidendom was in elk geval in lelieblanke Nederland van Penning se tyd nie ongewoon nie. Trouens, Penning het in die hoogty van kolonialisme gelewe. 'n 
Literêre beeld van die Europese (Nederlandse) houding teenoor gekleurdes kom voor in Multatuli se beroemde Max Havelaar wat reeds in 1859 'n skerp manifes is teen die hovaardige en uitbuitende houding van Nederland en Nederlanders teenoor die inheemse bevolking in die destydse Nederlands-Indië. Ds. Wawelaar, een van Multatuli se karakters en die predikant van Droogstoppel, spreek hom neerbuigend uit oor die inlandse bevolking: "Slaat het oog op de eilanden des Indischen Oceaans, bewoond door millioenen en millioenen kinderen des verstooten zoons ... van den edelen godgevalligen Noach" (Multatuli, 1969:100).

Kolonialisering wat meesal geïnspireer is deur state se magsug en ekspansiedrang is dikwels geimplementeer onder die dekmantel van 'n edel roeping tot bekering van die heidene of die gekoloniseerdes wat as onvolwasse en kinderlik beskou is en wat volwassenheid in die geloof moes bereik. Dat daar neergesien is op anderskleuriges - ook selfs in teologies ortodokse kringe - was onbetwisbaar. Penning, die seun van 'n predikant en self sterk godsdienstig behoudend, het dié houding in 'n sekere sin eintlik eiesoortig omvorm en vertolk en die idee van swart mense as Gamskinders en as houtkappers en waterdraers in sy werk gepropageer.

Jonckheere (1999:6) meen dat Abraham Kuyper (1837-1920), teoloog en politikus, ook seer seker 'n invloed op die denke oor rasseverhoudinge moes gehad het. Kuyper, aldus Jonckheere, het hom op Genesis 9:25 beroep “... waar staan dat Kanaar, die seun van Gam, tradisioneel beskou as die aartsvader van die swart ras, deur Noag vervloek is en 'n kneg van knegte moet wees vir sy broers". Hierdie soort idees moes in Penning se tyd posgevat het en seer seker die standpunte wat hy oor rasseverhoudinge in sy werke na vore bring, beïnvloed en gevorm het.

Swart mense word oor die algemeen in die gegewe teks gestereotipeer as onbetroubaar - hulle is die spioene vir die Engelse en hoewel die Engelse self nie veel vertroue in hulle het nie, aanvaar 'n Engelse kolonel die swart verkenner se woord as laasgenoemde terugkom van 'n verkenningstog: "'t Is waar, ' $t$ is een Káffer, doch déze Kaffer is te vertrouwen ... en de kolonel gelooft hem graag" (s.j.a:43).

Later word die onbetroubaarheid bevestig wanneer die Engelse uitoorlê word en die kolonel weer sy "kafferspioen" teekom. Dan word hy as 'n "gemene bedrieger" (p. 49) bestempel en in boeie geslaan. Wanneer die Engelse troepe deur 'n byna arkadiese landskap beweeg met 'n trop skape wat vredig wei, verwys die verteller na die omgewing wat "ontsier" word deur 'n "paar luie Kaffers" (p. 61) wat lustig lê en snork.

Wanneer ouderling Bezuidenhout op 'n Sondag 'n stigtelike woord moet spreek, verwys hy ook na die Boere se stryd teen die swart volke van Suid-Afrika. Die 
beproewinge op hierdie tydstip hou egter verband met die stryd teen die Engelse - dit is die vyande van buite. Maar meer nog daar is die stryd binne "... met grimmige beesten en nog grimmiger Kaffers ..." (p. 67).

Tog is daar ook positiewe uitbeelding. Dit is byvoorbeeld die geval met die swart huishulp van die Potgieters. Haar naam is Trijn, 'n ietwat ongewone naam vir 'n swart vrou, maar wel 'n naam wat dikwels aan die diensbode in Nederlandse huishoudings gegee is en wat dikwels voorkom in Nederlandse romans van die einde van die vorige eeu en ook in die begin van hierdie eeu. In die Nederlandse roman kom sy dikwels voor as die gesette, sagmoedige en lojale vrou met ' $n$ groot hart. Wanneer die Suid-Afrikaanse Trijn die Engelse offisier sien neertuimel, "giert [zij] het uit van plezier" (p. 22). Sy skaar haar aan die kant van haar huismense wanneer sy die Engelse as 'n "dom volk" bestempel.

So word die swart mense soms deel van 'n idilliese ruimte: op Wonderfontein, die plaas waar Louis Wessels ernstig siek lê, word 'n toneel beskryf van die strooise waar die kinders kaal in die sand speel en "... rukken elkander in het lange (sic) ongekamde kroeshaar. Doch hun moeders, die in versleten wollen dekens buiten tegen de rieten wanden hunner hutten zitten, heffen hun vingers soms dreigend op, als die kleine zwartjes te veel leven maken, en zeggen dan: 'Stil, Shilling; rustig Columbus, want ons baassie is banjer ziek!'” (p. 145).

Efraim, die swart opsigter van die plaas, is weer ' $n$ betroubare helper. Hy is vol vertroue dat Louis Wessels sal herstel en lê in die ysige koue by die buitedeur om naby die "jonge baas" te wees. Die verteller voeg hieraan toe dat Efraim nie die koue voel nie, want hy wat "... tot het verachte Kaffergeslacht behoort, heeft een warm hart" (p. 149).

Later word verwys na "de zware loden slagboom die Afrikaner en Kaffer scheidde ...", maar 'n slagboom wat dan wel voor die gloed van die Christelike liefde gesmelt het (p. 154). Dit is daarom dat ou Efraim deel het aan die verrigtinge van die klein gemeente daar op Wonderfontein waar gedank word vir die herstel van Louis Wessels.

Die houding ten opsigte van die swart man is vervat in die siening van die held, Louis Wessels, wanneer hy na die slag by Spioenkop met 'n swart man gekonfronteer word wat reddingbringende voorrade aflewer:

$\mathrm{Nu}$ eerst zag Louis de jonge Kaffer, die beladen was met gevulde veldflessen en verbandmiddelen, en hij voelde een onweerstaanbare drang, om de Kaffer de hand te drukken.

Het was misschien de eerste keer in zijn leven, dat zijn hand in die van een zoon van Cham nuste, maar hij voelde levendiger dan ooit, dat God machtig is, de liefde tot de naaste ook in te planten in het hart van de diep verachte Kaffer, en in dit ontzaglik ogenblik, waarin de dood over de 
Spionkop brulde, vielen de scheidsmuren neer tussen blanke en zwarte (p. 187).

Oor die algemeen kan 'n mens sê dat die implisiete verteller met 'n neerbuigende patriargale houding oor die swartes praat. Die woord Kaffer het egter nog nie die sterk pejoratiewe, beledigende inhoud gehad wat dit wel met verloop van tyd gekry het.

\subsection{Die ideologie van 'n heilige oorlog}

Dat die Boere 'n ideologiese stryd gevoer het, word in die teks geëksplisiteer. Die Engelse is die verdrukkers van die vrome nasie wat as ' $t$ ware in 'n heilige oorlog hulle land en besittings verdedig. Die Engelse word bestempel as die verteenwoordigers van die imperialisme en kapitalisme “... de van gouddorst jankende wolf ..." (p. 30).

Die heiligheid van die oorlog en die parallelle met die stryd van die volk Israel vanouds word 'n leitmotief in die teks. Die verteller laat genl. Louis Botha die volgende woorde besig:

Wij hebben het recht aan onze zijde, Wessels: wij hebben de God onzer vaderen, Die voor ons is geweest een toevlucht van geslacht tot geslacht, aangeroepen als de Scheidsrechter in deze gruwelike oorlog, en wij zullen 't niet opgeven ... omdat wij verdedigen het heilige pand, dat de Heere aan onze handen heeft toevertrouwd (p. 31/32).

Uiteindelik word die gegewe in 'n losser konteks, histories gesien, ironies: ondanks die beklemtoning dat God aan hulle kant staan, word die oorlog uiteindelik vir die Boere 'n ramp

In die hitte van die stryd sê Louis Wessels:

'Vrienden ... wij zullen vandaag voor de dierbare vrijheid van ons volk moeten vechten ... Wij hebben de roeping ontvangen om onze onafhankelikheid te verdedigen tegen het geweld van de vijand - zo laten wij blijmoedig onze laatste bloeddroppel geven voor de heilige zaak van het recht!

... wij hebben God en Zijn heilig recht aan onze zijde ...' (p. 36) (my kursivering).

Op 'n Sondag, by 'n vredig kabbelende Blaauwkransrivier, is dit die verteller wat verwys na die "heilige strijd voor vrijheid" (p. 64) maar ook die prediker, ouderling Bezuidenhout, lewer 'n vurige pleidooi oor "ons heilig recht" en 'n stryd waarin Chamberlain gesien word as 'n dienskneg van "vorst Satanas" (sic) (p. 67), maar in alles, so sê hy, "... hebben [wij] God en het recht aan onze zijde" (p. 69). 
By die slag van Colenso is dit Louis Wessels wat sy manne weer oproep tot die heilige stryd. Met 'n volstruisveer op sy hoed wys hy die pad "... in de heilige strijd voor vrijheid en recht. .." (p. 132).

In die helfte van die stryd roep "zwarte Albert" dat dit "... een dag der wrake is ... Zie, daar komen ze weer aan met grote troepen, als hongerige wolven, doch wij zullen ze verslaan in de mogendheden des Heeren Heeren!" (p. 140).

En die verteller kan nie nalaat om 'n vergelyking te tref met Joab vanouds nie wat "... drieduizend jaar geleden, de oorlogen des Heeren streed tegen de onbesneden Filistijnen ..." (p. 140).

Na die legendariese slag van Spioenkop is dit die verteller wat die laaste woord het. Louis Wessels en Truida Uijs doen op die "morgen van licht en zegepraal" 'n dankgebed. Daarna verwys die verteller in sy slotwoord na die gesneuweldes: "En wij gedenken hunner in liefde en weemoed, en wij zullen hun gedachtenis in ere houden - want zie, zij zijn in de dood gegaan voor Vrijheid, Waarheid en Recht!" (p. 191; my kursivering).

Die verheerliking van die Boere en hul stryd is ongetwyfeld ook gevoed deur Penning se grenslose bewondering vir Paul Kruger. Penning vertel in sy outobiografie van sy besoek in 1900 aan Kruger in Hilversum en beskryf hom as 'n "zuil van graniet", “... de Transvaalsche leeuw, de Mozes, de leider van zijn volk ..." (s.j.b:152).

Die waarskynlik outentieke woorde van Kruger aan Penning was dat die Boere die oorwinning sou smaak: “... Mogelijk in deze oorlog; mogelijk over vijftig jaar. Deze oorlog is slechts een schakel in een worsteling van een eeuw, en deze worsteling zal eindigen met de zegepraal van het recht" (s.j.b:153).

\section{Idealisering}

Die ideologiese aspekte van die werk word ondersteun deur 'n oormatige idealisering van persone en ruimtes. Persone word gesien deur 'n heroïese bril en die ruimtes waarin hulle beweeg, kry soms arkadiese trekke.

Die Afrikaners is onkreukbaar van karakter en vorm in hulle boere-adellikheid 'n sterk kontras met die hovaardige whiskey-drinkende Kakies.

\subsection{Persone en ruimtes}

Wanneer die vrou van Jan Potgieter (p. 7) op die toneel verskyn, word alles oor en rondom haar positief uitgebeeld.

Sy is druk besig "... met kousen stoppen ...", maar sy is oplettend, met "een spiedende blik naar buiten". Sy is sterk, "een kloeke vrouw van ruim dertig 
jaren" met reëlmatige gelaatstrekke, 'n vasberade plooi om die mond en helder grys oë".

Die ruimte wat haar omring, word eweneens positief geteken: Buite werp die namiddagson sy strale oor "weelderige" wijngaardranken" (p. 7). Binne sit sy by 'n "stevige vierkante tafel". Verder getuig alles van 'n "grote eenvoud" met as fokuspunt "een keurig onderhouden Statenbijbel met "blinkende koperen sloten" (p. 7; my kursiverings).

Wanneer die baas van die plaas, Jan Potgieter, daar aankom, word hy deur die verteller geskilder as 'n stereotipe van die egte Afrikaner: “... doch bij alle eenvoudigheid, die deze man kenmerkt, tekent zijn gezicht die schranderheid en iets van die slimheid, die de echte Afrikaner schijnt aangeboren" (p. I1).

Die idealisering van die Afrikaner word versterk deur die kontrastering met die Engelse. 'n Offisier wat met sy troepe op die werf aankom op soek na 'n Boerevlugteling word só uitgebeeld: "Hij blaakt van dienstijver, wat zeker te prijzen is, doch hij heeft daarbij een driftig opvliegend temperament, en zijn gelaat wordt op dit ogenblik ontsierd door een onaangename trek van stijgende wrevel" (p. 15; my kursivering).

Met die uitbeelding van Boer en Engelsman is 'n patroon gevestig waarvan eintlik nie afgewyk word nie: die Boer is steeds onberispelik en die Engelsman kwaadaardig, dom en onbeholpe, karikatuuragtig en soms dranksugtig. By die eerste kennismaking met die Engelse is dit die "... dikke Cas met het rode jenevergezicht" (p. 21) wat 'n sopie by die boervrou kom bedel. Later is dit die trotse offisier van die Engelse husare-eskadron wat van die leer aftuimel wat die "dienstmeid" laat skaterlag en die onnosele Hannes "kluchtige luchtsprongen" (p. 22) laat maak.

Wanneer die Engelse die Potgieters se plaas kom afbrand, is die lansiers "opgewonden door de whiskey" en is "de duivel der zinnelikheid ... in hun ogen .." (p. 91) sigbaar. Hulle poog selfs om Potgieter se vrou onsedelik aan te rand Wanneer hulle betrap word, is dit Louis Wessels wat opdrag gee dat hulle geboei en aan die sterte van die perde vasgebind word, want sê hy, “... het zijn beesten" (p. 93).

Op allerlei maniere word die Engelse uitoorlê. Hulle bestorm 'n verlate kamp en skiet op 'n strooipop wat die Boere agtergelaat het om die Engelse te mislei. Dit is 'n Boerespioen wat hom as 'n eierverkoper vermom en daarin slaag om die Engelse se verdedigingslinie binne te dring en om sodoende belangrike inligting aan die Boeremagte oor te dra.

As vergestalting van die Boereheldedom dien Blikoortje, 'n knaap wat onbevrees en lakoniek die stryd aandurf, 'n onblusbare eetlus het en ongelooflike heldedade doen met "zenuwen van staal" (p. 45). Hy kom ook in ander werke 
van Penning voor en was op die piek van die "Penning-hoogkonjuktuur" 'n huishoudelike naain vir die jeugdige Nederlandse leespubliek.

Die enigste gunstige beeld wat van die Engelse oorgedra word, is hulle ordelikheid en dissipline. In die groot kamp van Chievely, voor die Slag van Colenso, lyk dit asof daar 'n onbeskryflike wanorde heers, maar tog is daar "de grootste orde, omdat ieder wist wat hij te doen had" (p. 123). En swart Albert kyk deur sy verkyker met 'n trek van bewondering na "... de orde, de regelmaat, de krijgstucht" (p. 124) in die Engelse kamp en hy wonder met kommer oor "... de meer dan losse band, die de Boerenkommando's bijeenhield ...".

So is die karakterisering van Boer en Brit eenvoudig gesetel binne die paradigmas goed en kwaad, slim (uitgeslape) en dom (onnosel), godvresend en genadeloos. Die afwykings van hierdie paradigmas is minimaal. Die klem lê steeds op die adel en onberispelikheid van die Afrikaner-Boerestryders.

\section{Die historiese omraming}

Die hierbo bespreekte idealisering en ideologisering vind plaas binne die raamwerk van histories-feitelike gegewens, hoewel die historisiteit en feitelikheid juis deur die prosesse van idealisering en ideologisering ondermyn word. Enkele sake in dié verband word toegelig.

\subsection{Die verbintenis met Nederland}

Historiese werklikhede word wel vermeld. Daar is selfs verwysings na historiese heldedade uit die Nederlandse volksgeskiedenis. So byvoorbeeld word die heroïese ontsnapping van Hugo de Groot uit sy gevangenskap genoem. Hy ontsnap naamlik uit die Slot Loevestein deur in 'n boekkis weg te kruip (p. 14). Daar is origens 'n meningsverskil tussen Potgieter se vrou en Louis Wessels of die ontsnapping in ' $n$ boekkis of ' $n$ doodskis was.

Die verteller kan ook nie nalaat om die verbondenheid van Nederland en die Nederlandse vorste van Oranje met die Boerestryd te beklemtoon nie:

... in die zonneglans staat gij immer voor onze ogen getekend, gij helden van Zuid-Afrika, en uw moed en dapperheid zullen bij ons in eerbiedige herinnering blijven, zolang er nog een Nederlandse kiel de baren zal klieven, en zolang er nog een Hollandsch lied zal klinken langs onze duinen! (p. 57)

Louis Wessels het selfs 'n oranje lint aan sy hoed en hy wys daarna wanneer hy vir 'n paar bittereinders sê: "Houdt dit oranjelint maar in 't oog, broeders; waar Oranje is, daar is de zegepraal!" (p. 57). 
Daar word ook vergelykend verwys na die Oranjeprins Maurits se legendariese veldtog in 1600 toe hy die Spanjaarde by die Slag van Nieuwpoort verslaan het (p. 130). Jonckheere (1999:12) sê dat Penning met die lê van hierdie verbande sy Nederlandse lesers waarskynlik daarvan wou oortuig dat die Boere se stryd ook ' $n$ Hollandse stryd was waarin albei nasies se trots aangetas is.

\subsection{Historiese gebeure uit die Anglo-Boereoorlog}

Benewens die verwysings na talle plaaslike feitelike gebeurtenisse, byvoorbeeld die Slag van Bloedrivier (in ouderling Bezuidenhout se preek), is daar heelwat ander verwysings na feitelike gebeurtenisse uit die Anglo-Anglo-Boereoorlog self, onder andere die Slag van Colenso en die Slag by Spioenkop waarna die titel ook verwys.

Historiese Britse figure word vermeld, onder andere generaal Woodgate wat sou sneuwel en kolonel Thorneycroft. In Creswicke se werk South Africa and the Transvaal War (1900) word vermeld hoe verradelik die Boere teen hom opgetree het:

... dodges with the white flag and other frauds continued to be practised by the Boers. Colonel Thomeycroft escaped merely by an accident from an endeavour to play a trick upon him. The leader of a commando facing Thomeycroft's horse advanced with a white flag. The Colonel approached to the parley, but being suspicious, he told the leader to go back, as he refused to confer with him. Both retired, but before the Colonel could return to his regiment a volley was poured on him by the enemy (Creswicke, 1900:110).

Penning, op sy beurt, laat Thorneycroft die hasepad kies "... overstelpt door de jammer van zijn zwaar gehavende bataljons, en geen uitkomst meer wetend, gaf hij bevel tot de terugtocht" (p. 189).

Daar is wel 'n ooreenkoms in die beskrywing van die slagveld. Penning (p. 187) praat van die "veld des doods, dat sterke mannenharten zou doen beven". Creswicke (1900:112) noem die slagveld by Spioenkop 'n "veritable hell".

Dit het duidelik geword dat Penning die Boere en hulle krygsverrigtinge oormatig heroiseer. Creswicke se werk is histories baie meer betroubaar en bevat die verslag van 'n noukeurige betragter, hoewel daardie betragter Engelsgesind was. Adjektiewe soos "glorious" en "gallant" kom by herhaling in die beskrywings voor. Creswicke laat tog nie na om die Boere aan te prys nie vanweë hulle "persistency" (1900:108). In 'n ander paragraaf maak hy met verwysing na die Boere die volgende opmerking: "Their rushes were most valiant and persistent ..."(1900:110). 


\section{Samevattend}

Penning het, spesifiek in die bespreekte werk, seker nie die bedoeling gehad om feite te registreer nie; hy het eerder gefiksionaliseer en historiese feite binne daardie fiksie verwerk en so 'n eienaardige mengsel van feit en fiksie geskep. In Nederland en vanuit Nederland het hy 'n beeld van die oorlog geskep wat hoegenaamd nie objektief was nie.

By die gewone Nederlandse leser van sy tyd en ook by die latere lesers van sy werk, wat nie vertroud was met die feitelik-historiese omstandighede van die Anglo-Anglo-Boereoorlog nie, het hy 'n ongewone en ongelooflike sukses behaal. Sy werke het nie net 'n geidealiseerde beeld van die oorlog geskep nie, maar ook die Afrikaner, sy taal en sy godsdiens geïdealiseer. Die effek van hierdie idealisering het tot ver in die twintigste eeu gestrek.

In 1964 skryf Ben van Kaam dat die referensiekader van die gemiddelde Nederlander van Suid-Afrika grotendeels deur Penning gevoed is: "'n Afrikaner kan geen groter verbijstering by 'n Nederlander wek nie dan deur te laat blyk dat die naam Penning hom niks vertel nie". Wat Van Kaam in 1964 gesê het, is nog steeds waar, veral met betrekking tot die gemiddelde Nederlander in sy vyftigerof sestigerjare. Van Kaam vertolk die gevoel van baie Nederlanders wat Penning se boeke gelees het:

Hoe het ek nie die Rooibaadjies, die Rooinekke of die Kakies gehaat nie, hulle wat al vegtende hoenders gesteel en plase afgebrand het. Emmers vol whiskey het Penning die Engelse lansiers laat uitdrink. Uiters gemene karakters onder die Engelse het rooi snorre gedra. En as daar per ongeluk 'n enigsins menslike gestalte onder die vyande was, dan was dit gewoonlik 'n Ier of 'n Skot wat deur armoede gedwing is om te gaan veg om 'n arme moeder iewers in Europa te kan onderhou.

Met hierdie beskrywing gee Van Kaam eintlik toe dat hy slagoffer van Penning se stereotiperende beeldskepping geword het.

Dis origens interessant dat Penning se boeke gedurende die Tweede Wêreldoorlog (1940-1945) 'n soort propagandamiddel teen die Geallieerde Magte was: "In die oorlog het die Nazi's dan ook vakkundig op ons haat vir die Britte gespeel" (Van Kaam, 1964). Vir Van Kaam was dit 'n skok om te sien dat Penning se boeke, in die oorlogstyd (1940-1945) prominent in 'n boekwinkel van die pro-Nazi Nasionaal-Sosialistiese Beweging (die NSB) uitgestal was: "Die Reg het tog aan die kant van die Boere gestaan? Hoe kan 'n verkeerde party die boeke dan aanprys?", vra Van Kaam hom dan af.

Die literêre waarde van Penning se werke, wat herdruk op herdruk beleef het, is beperk. Dis eintlik maar net die herdenking van die feit dat die AngloBoereoorlog 100 jaar gelede begin het wat die belang van sy werk tydelik 
aktualiseer. Wat wel baie belangrik is, is dat Penning op ' $n$ ander deel van die aardbol meegehelp het aan die skepping van 'n beeld, sy dit dan 'n vertekende beeld, van wat op die slagvelde plaasgevind het.

Ook moet die sosiale gevolge van sy werke nie onderskat word nie. Ondanks die katastrofe van apartheid en die vernietigende gevolge daarvan vir die beeld van die Afrikaner het die heroïserende beeld wat Penning deur sy werke van hulle geskep by baie Nederlanders - tot ver na die Tweede Wêreldoorlog - as ' $n$ soort teenwig gedien. Daar word selfs beweer - hoewel dit moeilik kontroleerbaar is dat Penning tientalle jare na sy dood met sy werke ' $n$ invloed gehad het op die emigrasiesyfer van Nederlanders na Suid-Afrika. Toe emigrasie vanuit Nederland na 1945 tot in die sestigerjare in die mode was, was die geïdealiseerde beeld wat Penning van Suid-Afrika en die Afrikaner en sy taal geskep het, soms deurslaggewend by die besluit van 'n voornemende immigrant om juis SuidAfrika as sy nuwe vaderland te kies. Jonckheere (1999:12) sê die volgende in verband hiermee: "Omdat sy [Penning se] romans so volgeprop was met aksie (avonture, veldslae, agtervolgings, ontsnappngs, ens.) het die Hollandse jeug die ideële boodskap sonder enige probleem gesluk. Generasies jong mense is gekondisioneer deur die denke, ook toe hulle net na die Tweede Wêreldoorlog in groot getalle na Suid-Afrika geïmigreer het."

\section{Bibliografie}

Creswicke, Louis. 1900. South Africa and the Transvaal War. Vol. iii. Endinburgh/Cape Town: Jack \& McConnell.

Jonckheere, W.F. 1999. Nasie en mite: Nederland en die Anglo-Boereoorlog Acta Varia, 1:115. (D.F. Malherbe gedenklesing 18.)

Jonker, E. 1969. Wie was Oubaas Penning. Die Voorligter: 8 e.v., Jun.

Multatul. 1969 Max Hovelaar. Amsterdam : Van Oorschot. (Inl. G. Stuiveling.)

Penning, L. s.j a De held van Spionkop. Zwolle : La Riviére \& Voorhoeve. (Vierde druk.)

Penning, L. s.j.b. Uit mijn leven Zwolle : La Riviére \& Voorhoeve (Postuum.)

Penning, L s.j.c. . De helden van Zuid-Afrika: een verhaal uit den "trek" der Afrikaansche Boeren uit de Kaapkolonie naar de Transvaal. Gorkum : Duym.

Ras, J L. 1981. Jan Lion-Cachet as kerkman. Potchefstroom : PU vir CHO. (Th D-proefskrif.)

Van Gorp, H et al. 1991 Lexicon van literaire termen Leuven : Wolters.

Van Kaam, B. 1964. S. A. se stille ambassadeur in Nederland. Die Volksblad (Byvoegsel), 10 Jan. 1964. 